\title{
MATHEMATICAL RESERVES VS LONGEVITY RISK IN LIFE INSURANCES
}

\section{Magdalena Homa}

University of Wroclaw, Wroclaw, Poland

e-mail: magdalena.homa@uwr.edu.pl

ORCID: 0000-0003-1735-5150

\section{(C) 2020 Magdalena Homa}

This is an open access article distributed under the Creative Commons Attribution-NonCommercial-NoDerivs license (http://creativecommons.org/licenses/by-nc-nd/3.0/)

DOI: 10.15611/eada.2020.1.03

JEL Classification: C58, G22, G17

\begin{abstract}
Insurers wanting to provide protection against unforeseen losses should establish an appropriate level of reserves, which should balance the risk borne by the insurer so as to guarantee the financial security of the insured. The system including the financing requirements tailored to the real risks is called the Solvency II. According to that the valuation of classic life insurance should consider the real risk, which includes risk of death and the change in value of money over time. This method of calculating reserves does not ensure the protection of collected funds by aggregation and the individual risk of longevity, which may negatively affect the long-term financial stability of insurers as well as the level of financial security for the insured. Therefore, the aim of this paper is to modify the calculation methods and, above all, to correct reserves within the period of insurance, taking into account the current expectation of the future projected length.
\end{abstract}

Keywords: longevity risk, Solvency II, required mathematical premium reserves.

\section{Introduction}

Insurance activity is subject to special supervision due to its social and economic importance. Many requirements are imposed on the insurance companies which aim to ensure their solvency and guarantee the security of the insured persons. The key aspect of the regulatory framework is the necessity to set the appropriate level of capital. The insurer wants to be protected against unforeseen losses based on the valuation of cash flows, which should determine its appropriate level, offsetting the insurer's risk so as to ensure the financial security of the insured. The system that contains the financing requirements tailored to the real risks that insurance companies are exposed to is Solvency II [Directive of the European Parliament and Council 2009/138/EC Art. 77]. Solvency II is based on the greater 
dependence of capital on the amount of risk taken by insurance companies. In other words, capital is enough to cover the actual risk. Valuations should be made based on their current value of disposal, i.e. the value should correspond to the current amount that the insurance company would have to pay if it were to immediately transfer its contractual rights and obligations to another insurance company. The methods for calculating mathematical premium reserves in traditional insurance can be found in the classic actuarial literature. The reserve is calculated as the actuarial value of the accrued future cash flows, which takes the actual risk into account. To achieve this goal, insurers' assets are to be valued on the basis of their real market value, (best estimate). Thus, an insurer wishing to be protected against unforeseen losses based on the valuation of cash flows should establish an appropriate level of provisions that will balance the risk borne by the subject of insurance, such as death risk in the case of life insurance (LI) or life expectancy in the case of endowment insurance (EI) - the risk of longevity.

The challenges associated with the longevity risk are related to the fact that the longevity trend will change in the future and will be different than those assumed in the original calculations. In other words, it is the risk of an inadequate estimation of the future mortality rate [Bartkowiak 2011]. As a consequence, insurance companies are not able to fully rely on official domestic indicators and must manage the risk of longevity on their own.

According to the International Association of Insurance Supervisors (IAIS), those who risk longevity will have to pay extra for each year of longevity underestimation. The IAIS emphasizes that life expectancy is rising faster than expected, thus challenging everyone that accepts responsibility for the risk of longevity (life expectancy), i.e. the potential risk associated with the growing life expectancy of the beneficiaries of insurance policies. In the opinion of the IAIS, institutions that take the risk of longevity should counteract the problems resulting from the increase in life expectancy [IAIS Global... 2014]. Since the observed changes in mortality rates imply unexpected increases in life expectancies, the corresponding actuarial values underlying the calculation are also mathematical reserves of contributions [Trzpiot 2015]. On the one hand, it has become important to manage the longevity risk using life-expectancy tables containing long-term trend forecasts forming the basis for estimating the expected life expectancy. On the other hand, insurers will be required to adjust their reserves during the insurance period.

The article examines whether insurance companies that meet the long-term risk of longevity should ultimately create higher accumulated capital in order to secure future payments. It investigates whether they should use a correction mechanism based on adjusted estimates of the expected future life expectancy of the insured, and if the creation of an additional emergency fund is a solution to the problem. 


\section{Review of the literature}

The longevity risk is one of the largest, although least understandable, types of risk to which both life insurers and pensioners are exposed [Crawford et al. 2008]. In particular, the risks associated with the payment of pensions and annuities which turned out to be longer than expected, are the main reasons for 'non-peace' in terms of the stability of existing savings products for pension purposes [Biffis, Blake 2013]. Therefore many aspects have been considered in the literature of the subject in terms of correctly modeling mortality processes as well as protecting against the risk of longevity. To reflect the future evolution of the mortality rate, deterministic modeling and analytical models were traditionally used. In recent years the ability of insurance companies to correctly read demographic trends has improved significantly, but pensioners and insurers that pay insurance products are still heavily exposed to longevity risk. In fact, even if they correctly predict mortality rates, there still remains uncertainty about their future tendencies, hence it is necessary to use stochastic models to correctly measure the systematic part of the risk. In connection with this, numerous works consider the use of a stochastic approach to modeling mortality dynamics, (for example: [Ballotta and Haberman, 2006; Biffis, 2005; Biffis and Denuit, 2006; Cairns et al. 2006; Cairns et al. 2008; Dahl, 2004; Dahl, Møller 2006; Milevsky, Promislow 2001; Renshaw, Haberman 2003; 2006). The use of stochastic models is now even more essential in connection with the development of the Solvency II system. To protect against the risk of longevity, securities associated with longevity of the base populations were proposed, assessedin Blake et al. (2006) and Ngai and Sherris [2011] among others. Dahl et al. [2008] were the first to examine the protection against the risk of systematic longevity using securities associated with long-term eternity. Existing research considers the benefits of using hedging strategies with financial risk measures.

In addition to the problems widely discussed in the literature regarding the correct modeling of longevity risk, the correct valuation of products related to longevity is of equal importance. However, this problem is discussed in the literature to a much lesser extent and refers to pension and annuity contracts. Traditionally, the valuation of annuity contracts was based on consolidated actuarial techniques that amortized the mortality risk, but these methods do not work in the context of the growing problem of long-term risk. Denuit et al. [2011] and Richter and Weber [2011] proposed concluding contracts in which benefits would be adjusted in time in accordance with the observed value of the longevity index. In these types of indexed contracts, pension providers reduce the risk resulting from longevity to the level of 'safe' (with the probability of a shortage) by creating an additional emergency fund. This fund is financed by the insured in the form of an additional fee, which either increases the contractual premium or reduces benefits. In Alho et al. [2012] the authors investigate the consequences of these changes. The problem of linking the benefits paid to mortality rates is also undertaken in the works of Goldsticker [2007], 
Kartashov et al. [1996] and van de Ven and Weale [2008]. Denuit et al. [2015] proposed an alternative (or complementary) way of sharing the risk of longevity which includes the correction of the deferred period, while maintaining payments at a constant level. This approach to the problem, however, does not include analysis from the point of view of life and longevity insurance, and the methods of calculating and adjusting their required reserves.

\section{The longevity risk}

Longevity risk applies to both individuals and entire cohorts. The individual risk of longevity (sometimes called specific longevity risk) refers to when a person lives longer than expected [Pitacco et al. 2009]. Individual risk of longevity can lead to negative consequences for individuals but does not pose a threat to the financial stability of the insurer. However, there is also a aggregated longevity risk, sometimes called the risk of a trend, which affects entire populations. Life expectancy will be longer than expected. In other words, it is the risk of the inaccurate estimation of the future mortality rate trend [Bartkowiak 2011]; together, the specific and aggregated risk of longevity is the total risk of longevity (see [Blake, Borrows 2001]). Similar to longevity risk is mortality risk defined analogously as the risk that a person or group of people will live shorter than expected. Logically, the increase in long-term risk is equivalent to the decrease in mortality risk and vice versa, showing why these terms are often used interchangeably in literature. The longevity risk can be decomposed into the following components:

- the risk that a someone will die earlier or later than expected (volatility risk),

- the risk of the incorrect estimation of the current level of mortality for a given population (risk of mortality rate),

- the risk of the incorrect estimation of the future trend in mortality rate (risk of mortality rate trend).

The risk of volatility and mortality rate are by nature a specific risk, and their impact may be reduced by diversification. This means that the people whose life expectancy exceeds that of the average can be balanced by those that do not live to the average, but the risk of trend is a systematicrisk and therefore non-diversifiable one. The risk of trend results from the possibility of unexpected changes in life expectancy resulting from changes in lifestyle, diet or technological progress. For insurance companies, the aggregated risk of longevity is particularly important, which plays a crucial role in the insurance valuation and its calculations, because the incorrect estimation of the further life expectancy of insured persons may result in the accumulated funds being insufficient to cover future benefits, and thus may disturb the financial liquidity of the insurance company [MacMinn et al. 2006]. 


\section{Cash flow in LI and EI insurance}

Each life insurance (LI) and endowment (EI) contract involves specific payment streams made by the insured (premiums) and the insurer (benefits). These payments create cash flows between the insurer and the insured, and the determination of their amount is essential for conducting policy valuation. The main role in these calculations is played by the present cash flows, i.e. the current equivalent of future payments.

Definition: The valuation of the financial stream $F_{t}$, i.e. the function of the currently present payments $t$ made during the period of time $T$, is determined by the following formula [Habermann, Pitacco 1999]:

$$
Z F_{t}(T)=\frac{1}{v(t)} \int_{T} v(\tau) d F(\tau)
$$

When calculating the insurance, the payment stream marked with the symbol $F(t)$ should include all payments resulting from the concluded contract. These payments can be divided into three groups:

- $\quad$ insurance premiums payable by the insured and pensions paid by the insurer,

- a benefit in the amount of the sum that the insured paid during the period of insurance in the case of the insured's death,

- $\quad$ benefits paid to the survivor until the end of the insurance period.

The following variables of individual payment streams were adopted in the paper:

- the premium paid by the insured at time $t$ is $\Pi(t)$,

- the amount of pension paid at time $t$ for disability is $r(t)$,

- the amount of the one-time payment paid by the insurer due to the insurance period ending is $d(n)$,

- a one-off benefit related to the death of the insured during the period of insurance at time $t$ is equal to $c(t)$.

The actuarial value of a payment in the classic life or endowment insurance is the expected value of the present value amount of benefit or premium. In life and endowment insurances, the actuarial value of the payment stream is calculated as the conditional expected value of discounted payments, provided by the entire history of the process and determined by the general formula [Bowers et al. 1997]:

$$
E\left[Z F_{t}(T \vee n) \mid \mathcal{F}_{t}\right],
$$

where $\left\{F_{t}\right\}_{0 \leq t \leq T}$ is filtration defining the process of history at time $t$.

The new solvency assessment system conforming to Solvency II is to be adapted to the real risks insurance companies are exposed to. In the case of insurance institutions, potential risks are specific to the types of contracts concluded and cash 
flows should be valueted in consideration of the total risk to which the insurer is exposed.This includes filtration providing the comprehensive information available at time tregarding insurance options, mortality and interest rates. Consequently the history (filtration) can be divided into groups which should be included in the valuation [Homa 2015a]:

- $\mathcal{L}_{t}$ is knowledge about contract options,

- $\mathcal{G}_{t}$ is knowledge of the value of a monetary unit,

- $\mathcal{H}_{t}$ is knowledge about the mortality process.

Filtration $\mathcal{L}_{t}$ interpreted as the contract options risk, determines the type of cash flows resulting from the concluded insurance policy. Furthermore it assumes that the financial market is ideal and everyone has the same knowledge about it, and that the information is obtained only from observation of the price process $S_{t}$ and the process of value of the monetary unit $\mathrm{B}_{\mathrm{t}}$. At that time, one assumes that the $\mathcal{G}_{t}$ is interpreted as knowledge obtained until $t$ is: $\mathcal{G}_{t}=\mathcal{G}_{t}^{S \wedge B}$. On the other hand, $\mathcal{H}_{t}$ is the knowledge obtained until time $t$ of the mortality process, and information about it determines the future life of the insured at the age of $x$, marked as $T_{x} \equiv T$. Therefore, it is assumed that: $\mathcal{H}_{\mathrm{t}}=\mathcal{H}_{t}^{T}=\sigma(\mathrm{I}(T>\mathrm{t}), 0 \leq t \leq n)$.

Thus, filtration $\mathcal{F}_{t}$ determines the comprehensive information available at time $t$ regarding the process of mortality and price formation takes the following form:

$$
\mathcal{F}_{t}=\mathcal{L}_{t} \wedge \mathcal{G}_{t} \wedge \mathcal{H}_{t} .
$$

Considering this filtration, the actuarial value of the payment was determined:

- for the end of the insurance period,

- for death during the period of insurance,

constituting the basis for further calculation of the reserves. Due to the survival of the determined moment $n$ (the end of the insurance period), the insurer will pay the insured the benefit. The present value at moment $t$ is $Z D_{t}(n)$ and is equal to:

$$
I\{T>n\} \cdot Z D_{t}(n)=I\{T>n\} \cdot \frac{v(n)}{v(t)} d(n) .
$$

Thus the actuarial value of the payment is equal to:

$$
\begin{gathered}
E\left[I\{T>n\} \cdot Z D_{t}(n) \mid \mathcal{F}_{t}\right]=E\left[I\{T>n\} \cdot Z D_{t}(n) \mid \mathcal{L}_{t} \wedge \mathcal{G}_{t}\right] \cdot E[I\{T>n\} \\
\left.Z D_{t}(n) \mid I(T>t)\right]=E[I\{T>n\} \mid I(T>t)] \cdot E\left[\frac{v(n)}{v(t)} d(n) \mid \mathcal{L}_{t} \wedge \mathcal{G}_{t}\right]={ }_{n-t} p_{x+t} \\
E\left[\frac{v(n)}{v(t)} d(n) \mid \mathcal{L}_{t} \wedge \mathcal{G}_{t}\right] .
\end{gathered}
$$

On the other hand, in the case of life insurance, the death payment is paid to the insured upon death (i.e. at time $T$ of insurance) and, similarly to the endowment insurance (EI), the actuarial value is equal to the following equation for the life insurance (LI): 


$$
\begin{gathered}
E\left[Z C_{t}(T \vee n) \mid \mathcal{F}_{t}\right]=E\left[I\{T \leq n\} \cdot Z C_{t}(T) \mid \mathcal{F}_{t}\right]= \\
E\left[\int_{t}^{T \vee n} \frac{v(\tau)}{v(t)} c(\tau) d I\{\tau \leq n\} \mid \mathcal{F}_{t}\right]=\int_{t}^{T \vee n} E\left[\frac{v(\tau)}{v(t)} c(\tau) \mid \mathcal{F}_{t}\right] \cdot E[d I\{\tau \leq n\} \mid I(T>t)]= \\
\int_{t}^{T \vee n} \frac{v(\tau)}{v(t)} c(\tau) \cdot E[I\{\tau \leq n\} \cdot \mu(x+\tau) \mid I(T>t)] d \tau= \\
\int_{t}^{T \vee n} \frac{v(\tau)}{v(t)} c(\tau) \cdot{ }_{\tau-t} p_{x+t} \mu(x+\tau) d \tau .
\end{gathered}
$$

The last type of benefit provided in the contract includes the payment of disability pension resulting from an accident. In order to value this type of cash flow, it was assumed that the future life of the insured person was classified as $T_{x}^{Z} \equiv T^{Z}$. The actuarial value of this type of annuity is equal to:

$$
\begin{gathered}
E\left[Z R_{t}(T \vee n) \mid \mathcal{F}_{t}\right]=E\left[I\left\{T^{Z} \leq n\right\} \cdot Z R_{t}(T) \mid \mathcal{F}_{t}\right]= \\
E\left[\int_{t}^{T \vee n} \frac{v(\tau)}{v(t)} r(\tau) I\{\tau \leq n\} \mid \mathcal{F}_{t}\right]=\int_{t}^{T \vee n} E\left[\frac{v(\tau)}{v(t)} r(\tau) \mid \mathcal{F}_{t}\right] \cdot E\left[I\left\{T^{Z} \leq n\right\} \mid I(T>t)\right] d \tau= \\
\int_{t}^{T \vee n} \frac{v(\tau)}{v(t)} r(\tau) \cdot{ }_{\tau-t} p_{x+t}^{Z} d \tau
\end{gathered}
$$

\section{Mathematical reserves}

The new solvency assessment system compliant with Solvency II is to be adapted to the real risks that insurance companies are exposed to. Therefore, taking into account the above extended filtration and the extended actuarial risk required under Solvency II, the reserve should be determined as a probability-weighted average of future cash flows [Homa 2015b]:

$$
V_{t}=E\left(Z W_{t}-Z \Pi_{t} \mid \mathcal{L}_{t} \wedge \mathcal{G}_{t} \wedge \mathcal{H}_{t}\right)
$$

where: $Z W_{t}$ is the present value at the moment $t$ payout value, $Z \Pi_{t}$ is present value atr the moment $t$ of the premium stream.

According to the above, and assuming the independence of the insurance and financial market that generate the history of the process, the following is obtained:

$$
V_{t}=E\left(Z W_{t}-Z \Pi_{t} \mid \mathcal{L}_{t} \wedge \mathcal{G}_{t}\right) \cdot E\left(I_{\{T>t\}} \mid\{T>t\}\right) .
$$

Assuming that ${ }_{t} p_{x}$ i $\mu(x+t)$ refers to the probability of survival and the intensity of mortality, and by using the derived formulas of the actuarial value of cash flows, the reserve formula takes the form of:

$$
\begin{gathered}
V_{t}={ }_{n-t} p_{x+t} E\left(Z W_{n} \mid \mathcal{L}_{t}\right)+ \\
\int_{t}^{T \vee n}{ }_{\tau-t} p_{x+t} \mu(x+\tau) E\left(Z W_{t} \mid \mathcal{L}_{t}\right) d \tau-\int_{t}^{T \vee n}{ }_{\tau-t} p_{x+t} E\left(Z \Pi_{t} \mid \mathcal{L}_{t}\right) d \tau .
\end{gathered}
$$


Knowing that there is a fixed rate and continuous capitalization market, the value of a monetary unit is equal to:

$$
B_{t}=e^{\delta t}
$$

and indexing the contract option risk and filtration $\mathcal{L}_{t}=\sigma(X(t)=j$, $j \in\{1,2, \ldots, k\})$, the level of required reserves at moment $t$, when $j-$ policy option is given by the formula:

$$
\begin{aligned}
& V_{t}^{j}=e^{-\delta(t-\tau)}{ }_{n-t}^{j} p_{x+t} W_{n}^{j}+\int_{t}^{T \vee n} e^{-\delta(t-\tau)}{ }_{\tau-t}^{j} p_{x+t} \mu(x+\tau) d W^{j}(\tau)+ \\
& \int_{t}^{T \vee n} e^{-\delta(t-\tau)}{ }_{\tau-t} p_{x+t} d \Pi^{j}(\tau)= \\
& e^{-\delta(t-\tau)}{ }_{n-t}^{j} p_{x+t} d^{j}(n)+\int_{t}^{T \vee n} e^{-\delta(t-\tau)}{ }_{\tau-t}^{j} p_{x+t}\left(\mu(x+\tau) c^{j}(\tau)+r(\tau)\right) d \tau+ \\
& \int_{t}^{T \vee n} e^{-\delta(t-\tau)}{ }_{\tau-t} p_{x+t} \pi(\tau) d \tau \text {. }
\end{aligned}
$$

In the above formula, the first two components are the present values of future payments, reduced by the current value of premiums paid. This is the capital which should be secured by an insurance company offering life and endowment insurance to secure funds for future payments, and its valuation can be made cyclically at any time during the insurance period. It is essential that all components are valued with the assumption of a certain longevity trend, but this changes the function. The observed changes in mortality rates imply unexpected increases in life expectancy, while the corresponding actuarial values of payments constituting the basis for reserves calculations increase. In the case of premiums valued at the time the insurance agreement is made, the actuarial value does not change as a result of a change in longevity. Therefore, in order to meet this long term risk, insurers should ultimately create higher or lower (depending on the type of contract LI or EI) accumulated capital to secure future payments.

In cases when the insurance company has a large portfolio, the law of large numbers states that the risk of death is diversified. This concerns the valuation of benefits, but the insurer in the calculation of premiums uses historical knowledge available at the time of conclusion of the insurance and mortality risk. So the changes of this risk during the insurance period cannot be included in the designated premium. This premium will not cover the real risk taken by the insurer, and the mathematical reserve created on its basis will not protect the collected funds by aggregated and individual risks of longevity which may negatively affect the long-term financial stability of insurers. Therefore, in the case of life and endowment insurance it is necessary not only to estimate the trend of the expected life expectancy of the insured, but above all to create an emergency fund resulting from the financial shortages arising during the insurance period due to changes in the risk of the mortality rate over time. In the case of mixed portfolios, it will be possible to cover shortages from life insurance from the surplus assigned to LI's insurance policies. 


\section{Application examples - results}

As an example, a contract of $n$-year standard life insurance (LI), endowment insurance (EI) and mixed insurance (ELI) was analyzed, along with additional contacts acknowledging the accident options:

- accidental death insurance (ADI),

- $\quad$ accident insurance (AI).

The subject of the basic insurance is the life of the insured. Under such, an insurance company pays out the amount of $\mathrm{c} \mathrm{m}$. u. (monetary unit) in the case of the death of the insured or the amount $\mathrm{d} \mathrm{m}$. $\mathrm{n}$. in the case of the insured living to the end of the insurance period. The subject of the additional contract is the health of the insured and the ADI and AI options cover full or partial permanent disability caused by an accident. Given this, an insurance company pays out usually double the insurance sum or the pension. Cash flows characteristic for this type of insurance are presented in Table 1.

Table 1. Payment streams for insurance

\begin{tabular}{|l|c|c|c|c|}
\hline Premiums & $\begin{array}{c}\text { Pension from } \\
\text { AI }\end{array}$ & $\begin{array}{c}\text { Benefit due to the end } \\
\text { of the insurance }\end{array}$ & $\begin{array}{c}\text { One-time benefit } \\
\text { due to ADI }\end{array}$ & $\begin{array}{c}\text { One-off payment } \\
\text { for death }\end{array}$ \\
\hline$\pi(t)=\pi$ & $r_{A I}(t)=r$ & $d(t)=d$ & $c_{A D I}(t)=2 c$ & $c(t)=c$ \\
\hline
\end{tabular}

Source: own study.

To determine the value of the required reserves, the present and actuarial values of the payment streams resulting from the concluded contract should be specified. The actuarial value of total cash flows for the insurance of LI, EI and ELI is presented in Table 2.

Table 2. Actuarial value of future cash flows for insurance with additional options AI and ADI

\begin{tabular}{|l|c|}
\hline \multicolumn{1}{|c|}{ Type of payment } & Actuarial value \\
\hline \multicolumn{1}{|c|}{} & 2 \\
\hline Premiums & $E\left[Z \Pi_{t}(T \vee n)\right]=\pi \int_{t}^{T \vee n} e^{-\delta(t-\tau)}{ }_{\tau-t} p_{x+t} d \tau$ \\
\hline Pension from AI & $E\left[Z \mathrm{R}_{t}(T \vee n)\right]=r \int_{t}^{T \vee n} e^{-\delta(t-\tau)}{ }_{\tau-t} p_{x+t}^{A I} d \tau$ \\
\hline Benefit due to the end of the insurance period & $E\left[Z \mathrm{D}_{t}(T \vee n)\right]=d e^{-\delta(t-\tau)}{ }_{n-t} p_{x+t}$ \\
\hline
\end{tabular}


Table 2, cont.

\begin{tabular}{|l|c|}
\hline \multicolumn{1}{|c|}{1} & 2 \\
\hline One-off payment for death & $c \int_{t}^{T \vee n} e^{-\delta(t-\tau)}{ }_{\tau-t} p_{x+t} \mu(x+\tau) d \tau$ \\
\hline One-time benefit due to ADI & $2 c \int_{t}^{T \vee n} e^{-\delta(t-\tau)}{ }_{\tau-t} p_{x+t} \mu_{A D I}(x+\tau) d \tau$ \\
\hline
\end{tabular}

Source: own study.

The value of reserves that an insurer should have at the time of the insurance period to cover future benefits resulting from the concluded policies depends on the policy's status. If at time $t$ the insured person is healthy and pays premiums, the required level of mathematical reserves should be calculated from the formula:

$$
\begin{gathered}
V_{t}=d e^{-\delta(t-\tau)}{ }_{n-t} p_{x+t}+c \int_{t}^{T \vee n} e^{-\delta(t-\tau)}{ }_{\tau-t} p_{x+t} \mu(x+\tau) d \tau+ \\
r \int_{t}^{T \vee n} e^{-\delta(t-\tau)}{ }_{\tau-t}^{T \vee} p_{x+t}^{A I} d \tau+2 c \int_{t}^{T \vee n} e^{-\delta(t-\tau)}{ }_{\tau-t} p_{x+t} \mu_{A D I}(x+\tau) d \tau- \\
\pi{ }_{t}^{-\delta(t-\tau)}{ }_{\tau-t} p_{x+t} d \tau .
\end{gathered}
$$

On the other hand, the activation of the additional option affects the change in the level of required mathematical reserves of the premiums that the insurer should have at time $t$ and they are equal to:

$$
\begin{aligned}
V_{t}^{A I} & =d e^{-\delta(t-\tau)}{ }_{n-t} p_{x+t}+c \int_{t}^{T \vee n} e^{-\delta(t-\tau)}{ }_{\tau-t} p_{x+t} \mu(x+\tau) d \tau+ \\
& r \int_{t}^{T \vee n} e^{-\delta(t-\tau)}{ }_{\tau-t} p_{x+t}^{A I} d \tau-\pi \int_{t}^{T \vee n} e^{-\delta(t-\tau)_{\tau-t}} p_{x+t} d \tau .
\end{aligned}
$$

Both formulas form the basis for calculating the mathematical reserves resulting from insurance with an insurance sum of 1000j.p and a risk-free rate of 5\%. In order to consider the changes in mortality risk in the future analysis and calculations to set the probability of survival and death, the following were used:

- current life tables (variant I),

- prognoses considering the longevity risk and changes in the mortality rate trend (variant II). 
On this basis the parameters of the mortality function were estimated $\mu(x+t)$ in two variants and in the intensity of an accident $\sigma(x+t)$, which was based on the Gompertz-Makeham model. The model describes the actual intensity of deaths considering factors depending on age which Gompertz had considered, who claimed that mortality is the result of two types of causes. The first one are illnesses which affect both young and old people equally, while the second cause is the decline in a human's ability to oppose death. Makehan, however, noticed that certain factors also affect this force regardless of age. These factors are aggregated and appear in the model in a constant form. The obtained model is called the Gompertz-Makeham law and the distributor has the following form [Ostasiewicz 2011]:

$$
F(x)=\left\{\begin{array}{ll}
0 & x \leq 0 \\
1-\exp \left(-A x-\frac{B}{C}\left(e^{C x}-1\right)\right) & x>0
\end{array} .\right.
$$

The maximum likelihood estimation of the parameters of the Gompertz-Makeham function of mortality are presented in Table 3.

Table 3. Estimators of the greatest credibility of the Gompertz-Makeham function

\begin{tabular}{|c|c|c|c|}
\hline $\begin{array}{c}\text { Parameters } \\
\text { gambling function }\end{array}$ & $\begin{array}{c}\text { Variant I } \\
\mu_{1}(x+t)\end{array}$ & $\begin{array}{l}\text { Variant II } \\
\mu_{2}(x+t)\end{array}$ & $\sigma(x+t)$ \\
\hline$A$ & 0.0000100 & 0.000475 & 0.0004 \\
\hline$B$ & 0.000143493 & 0.000068272 & $3.4674 \mathrm{E}-06$ \\
\hline$C$ & 1.0869039 & 1.091756 & 1.148153621 \\
\hline
\end{tabular}

Source: own study based on: http://repozytorium.uni.lodz.pl/:8080/xmlui/bitsream/handle/110 89/ 5393/Wiad\%20Ubezp\% 202003\%2011-12.pdf.

On this basis the appropriate probabilities were determined by solving the Chapman-Kolmogorov differential equations using a standard approach based on national mortality rates (variant I) and considering longevity risk based on trend forecasts (variant II). The level of required mathematical provisions for LI, EI and ELI insurance in variants I (continuous line) and II (dashed line) was determined and presented in the following areas ${ }^{1}$.

From Figures 1 to 3 it can be concluded that the risk of longevity does not affect the functional form of the mathematical reserves and does not change its structure during the insurance period. This means that LI contract reserves are an ascending-descending function of time with zero final reserve, whereas in the case of EI it grows with a non-zero final reserve.

\footnotetext{
${ }^{1}$ The calculations were made in Mathematica 8.0.
} 


$$
x=30, n=20
$$

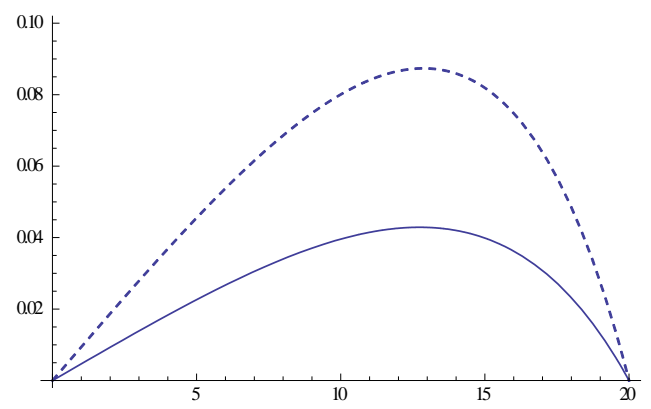

$x=50, n=20$

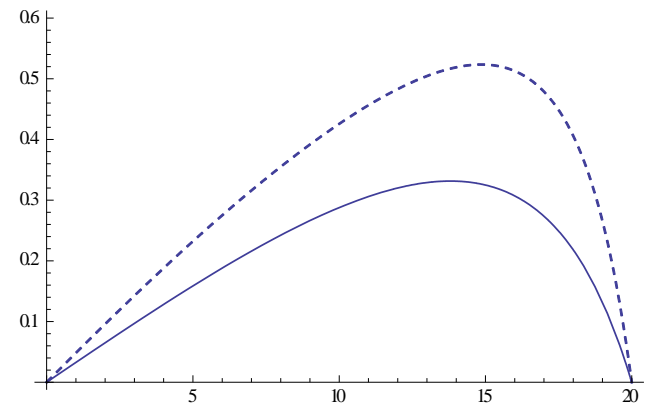

Fig. 1. Comparison of the amount of the required mathematical reserve in LI in variant 1 and 2 Source: own study.
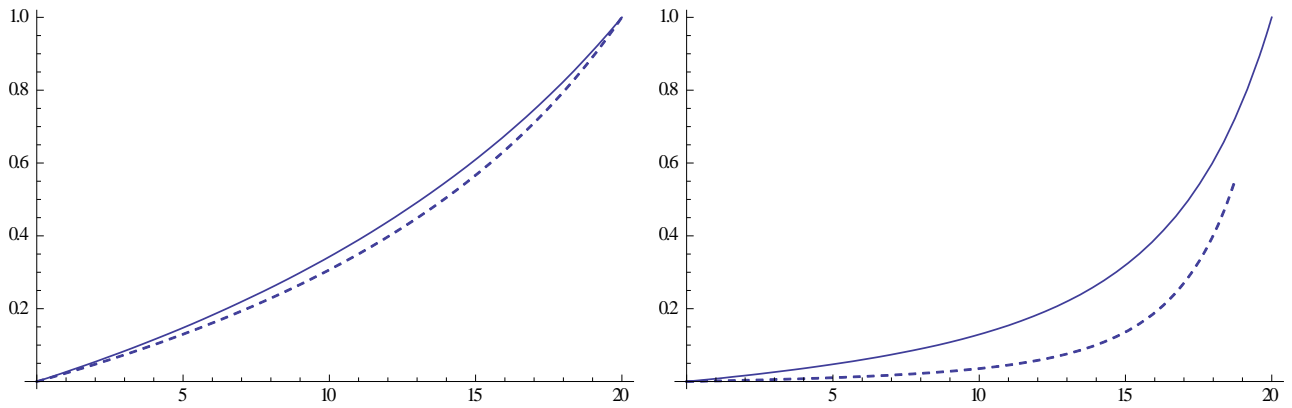

Fig. 2. Comparison of the amount of the required mathematical reserve in EI in variant 1 and 2 Source: own study.
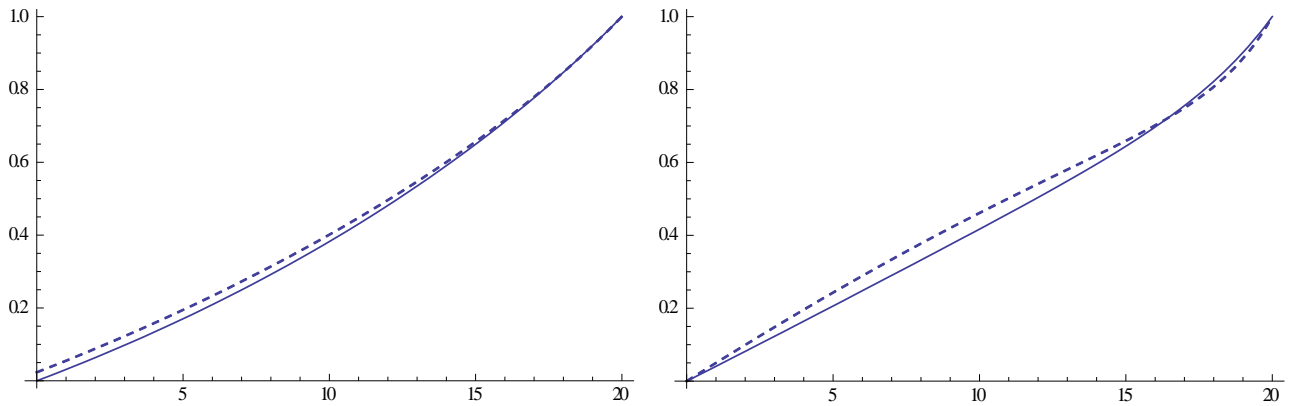

Fig. 3. Comparison of the amount of the required mathematical reserve in ELI in variant 1 and 2 Source: own study.

Depending on the type of basic contract (EI or ELI), a surplus or deficit of provisions is observed, which arises during the insurance period as a result of changes in longevity risk, as shown in Figures 4 to 6. 


$$
x=30, n=20
$$

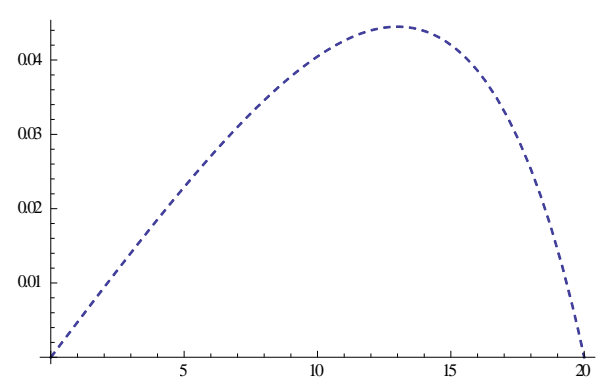

$$
x=50, n=20
$$

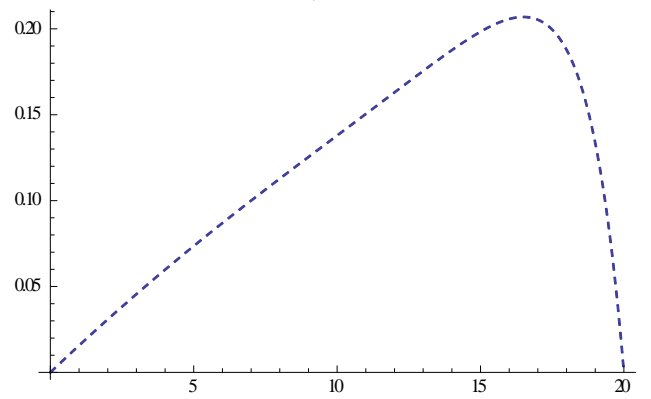

Fig. 4. The amount of surplus of reserves resulting from the risk of longevity during the period of LI contract

Source: own study.
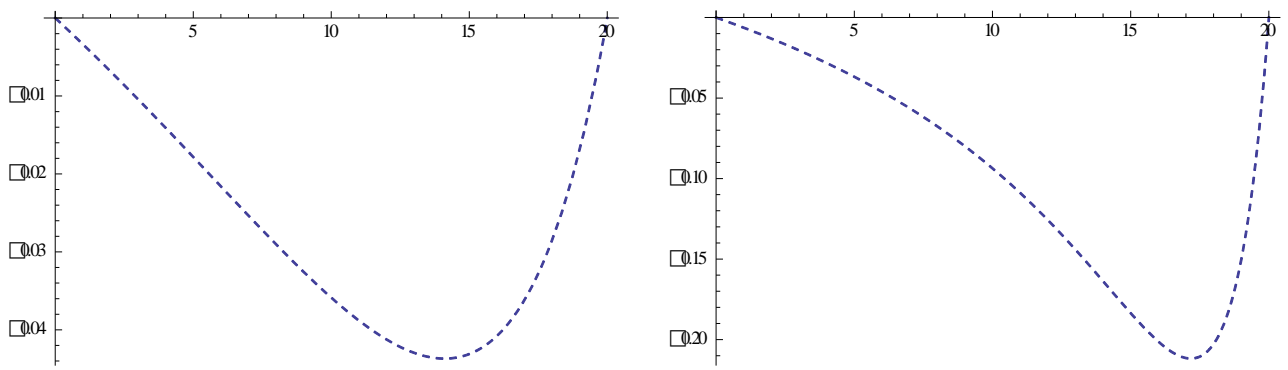

Fig. 5. The amount of deficit of reserves resulting from the risk of longevity during the period of EI contract

Source: own study.
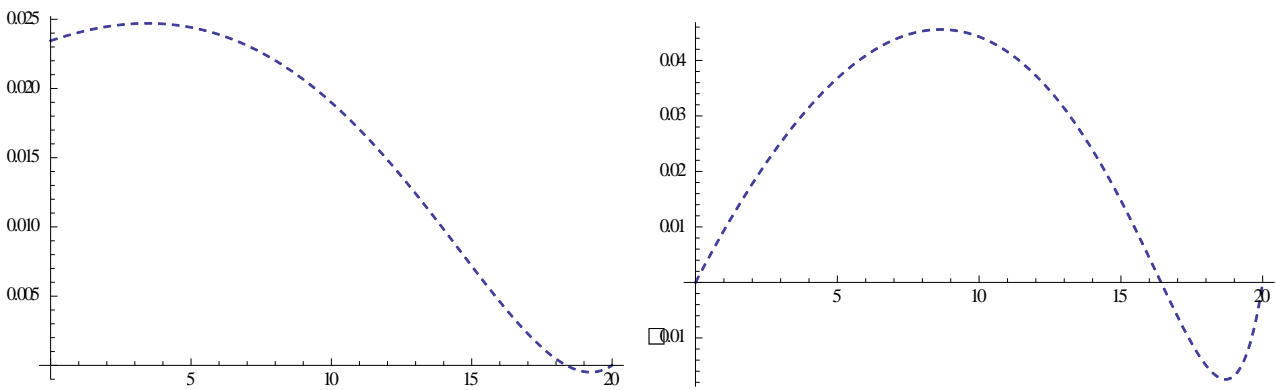

Fig. 6. The amount of surplus of reserves resulting from the risk of longevity during the period of ELI contract

Source: own study. 
Based on the above figures it can be clearly stated that the impact of longevity risk on the level of required reserves is different in the case of life insurance contracts LI, EI or ELI. Obviously this is due to the fact that the increase in the risk of longevity is equivalent to the decrease in mortality risk. Hence the incorrect estimation of the future mortality rate ratio translates into an initial overestimation of life insurance reserves and its present valuation in the case of life insurance. Therefore, financial shortages relate to EI insurance of a savings character because the risk of longevity significantly increases the amount of mathematical premium reserves required in accordance with Solvency II. In life insurance (LI), the insurer should create a reserve fund at a lower level, meaning that it could release these funds and use them to cover shortages arising from EI type insurance. However, at the same time, the results of the performed calculations confirm that the insurer offering a composite life and endowment insurance product must also collect a higher amount of basic reserves. Free funds are not sufficient to secure the insurer's solvency in the future without additional financial expenses.

\section{Conclusion}

In this work the prospective method has been presented to calculate insured value required for the so-called mathematical premium reserves, which is in accordance with Solvency II. The obtained results illustrate the impact of the choice of life expectancy tables on the conducted net premium calculations in insurance and confirm the significant impact of longevity risk on the revaluation or underestimation of provisions, depending on the type of contract and age of the insured persons. The research results show that, firstly, insurance companies cannot rely solely on official domestic indicators that form the basis for the valuation of life insurance upon entering into this type of insurance. This is means that it is necessary to introduce the dynamic life tables (DLT) in place of the traditional, which will allow the inclusion of an additional emergency fund in the calculations, intended to cover the risk of changing the trend, allowing for the elimination of the adverse impact of long-term risk. The obtained results confirm that the adjustment of provisions during the period of insurance, considering the risk of longevity and the creation of an emergency fund from the funds released from the use of UG, give the possibility of partial compensation, but the determination of the required funds at the level that secures the insurer's solvency absolutely requires additional financial expenditure.

\section{References}

Alho J., Bravo J., Palmer E., 2012, Annuities and life expectancy in NDC, [in:] Holzmann R., Palmer, E. Robalino, Non-Financial Defined Contribution Pension Schemes in a Changing Pension World, Politics and Financial Stability, World Bank Publications, vol. 2, Washington, 395-436. 
Ballotta L., Haberman S., 2006, The fair valuation problem of guaranteed annuity options: the stochastic mortality environment case, Insurance: Mathematics and Economics, vol. 38, 195-214.

Bartkowiak M., 2011,Transfer ryzyka dlugowieczności, Polityka Społeczna, no. 3, 22.

Biffis E., 2005, Affine processes for dynamic mortality and actuarial valuations, Insurance: Mathematics and Economics, vol. 37, 443-468.

Biffis E., Blake D., Keeping some skin in the game: how to start a capital market in longevity risk transfer, The Pensions Institute, Discussion Paper PI-1207, December 2013.

Biffis E., Denuit M., 2006, Lee-Carter goes risk-neutral: an application to the Italian annuity market, Giornale dell'Istituto Italiano degli Attuari, no. LXIX, 33-53.

Blake D., Borrows W., 2001, Survivor bonds: Helping to hedge mortality risk, Journal of Risk and Insurance, vol. 68(2), 339-348.

Blake D., Cairns A., Dowd K., MacMinn R., 2006, Longevity bonds: Financial engineering, valuation, and hedging, J. Risk Insurance, vol. 73(4), 647-672.

Bowers N.L., Gerber H.U., Hickman J.C., Jones D.A., Nesbitt C.J., 1997, Actuarial Mathematics, Society of Actuaries, Schamburg.

Cairns A.J.G., Blake D., Dowd K., 2006, A Two-Factor model for stochastic mortality with parameter uncertainty: theory and calibration, J. Risk Insurance, vol. 73, 687-718.

Cairns A.J.G., Blake D., Dowd K., 2008, Modelling and management of mortality risk: a review, Scandinavian Actuarial Journal, vol. (2-3), 79-113.

Crawford T., de Haan R., Runchey C., 2008, Longevity Risk Quantification and Management: Review of Relevant Literature, Technical Report. Society of Actuaries, US.

Dahl M., 2004, Stochastic mortality in life insurance: market reserves and mortality-linked insurance contracts, Insurance: Mathematics and Economics, vol. 35, 113-136.

Dahl M., Melchior M., Mřller T., 2008, On systematic mortality risk and risk minimization with survivor swaps, Scand. Actuar. J., vol. (2-3), 114-146.

Dahl M., Møller T., 2006, Valuation and hedging of life insurance liabilities with systematic mortality risk, Insurance: Mathematics and Economics, vol. 39, 193-217.

Denuit M., Haberman S., Renshaw A., 2011, Longevity-indexed life annuities, N.Am. Actuar. J., vol. 15, 97-111.

Denuit M., Haberman S., Renshaw A., 2015, Longevity-contingent deferred life annuities, J. Pension Econ. Financ, vol. 14(3), 315-327.

Directive 2009/138/EC of the European Parliament and of the Council, Article 77.

IAIS Global Insurance Market Report (GIMAR), 2014.

Goldsticker R., 2007, A mutual fund to yield annuity-like benefits, Financ. Anal. J., Vol. 63(1), 63-67.

Habermann S., Pitacco E., 1999, Actuarial Models for Disability Insurance, Chapman \& Hall/CRC, London.

Homa M., 2015a, Mathematical reserves in insurance with equity funds versus the real value of a reference portfolio, Research Papers of Wroclaw University of Economics Financial Investment and Insurance-Global Trends and the Polish Market 381, 86-97.

Homa M , 2015b, The impact of additional insurance options of the abd, ali and adi-type on the level of mathematical reserves of premiums in life insurance, Wiadomości Ubezpieczeniowe, 4, 63-78.

Kartashov V., Maurer R., Mitchell O.S., Rogalla R., 1996, Lifecycle portfolio choice with systematic longevity risk and variable investment linked deferred annuities, National Bureau of Economic Research, Cambridge MA. Working Paper 17505.

MacMinn R., Brockett P., Blakje D., 2006, Longevity risk and capital markets, The Journal of Risk and Insurance, vol. 73, no. 4.

Milevsky M.A., Promislow S.D., 2001, Mortality derivatives and the option to annuities, Insurance: Mathematics and Economics, vol. 29, 299-318.

Ngai A., Sherris M., 2011, Longevity risk management for life and variable annuities: the effectiveness of static hedging using longevity bonds and derivatives, Insurance: Mathematics and Economics, vol. 49(1), 100-114. 
Ostasiewicz S., 2011, Modelowanie trwania życia w populacjach niejednorodnych. Research Papers of Wrocław University of Economics, 230, 99-122

Pitacco E., Denuit M., Haberman S., Olivieri A., 2009, Modelling Longevity Dynamics for Pensions and Annuity Business, Oxford University Press.

Renshaw A.E., Haberman S., 2003, Lee-Carter mortality forecasting with age specific enhancement, Insurance: Mathematics and Economics, vol. 33, 255-272.

Renshaw A.E., Haberman S., 2006, A cohort-based extension to the Lee-Carter model for mortality reduction factors, Insurance: Mathematics and Economics, vol. 38, 556-570.

Richter A., Weber F., 2011, Mortality-indexed annuities: managing longevity risk via product design, N. Am. Actuar. J, vol. 15, 212-236.

Trzpiot G., 2015, Finansowe implikacje ryzyka dtugowieczności, Studia Ekonomiczne. Zeszyty Naukowe UE w Katowicach, nr 241.

van de Ven J., Weale M., 2008, Risk and mortality-adjusted annuities, National Institute of Economic and Social Research, London, Discussion Paper, 322.

\section{RYZYKO DLUGOWIECZNOŚCI A WYMAGANY POZIOM REZERW W UBEZPIECZENIACH NA ŻYCIE I DOŻYCIE}

Streszczenie: Ubezpieczyciel, chcąc zabezpieczyć się przed nieprzewidzianymi stratami, powinien ustalić odpowiedni poziom rezerw, które powinny zrównoważyć ponoszone przez ubezpieczyciela ryzyko, tak aby zapewnić bezpieczeństwo finansowe ubezpieczonych. System zawierający wymogi finansowania dopasowane do rzeczywistych typów ryzyka to Solvency II. Zgodnie z nim wycena klasycznych ubezpieczeń na życie powinna uwzględniać rzeczywiste ryzyko, które obejmuje: ryzyko śmierci oraz zmianę wartości pieniądza w czasie. Taki sposób kalkulacji rezerw nie zapewnia ochrony gromadzonych środków przed zagregowanym i indywidualnym ryzykiem długowieczności, co może negatywnie wpłynąć na długoterminową stabilność finansową ubezpieczycieli, a także na poziom zabezpieczenia finansowego ubezpieczonych. W związku $\mathrm{z}$ tym celem artykułu jest modyfikacja sposobów kalkulacji, a przede wszystkim korekty rezerw w okresie trwania ubezpieczenia z uwzględnieniem aktualnego trendu dalszej oczekiwanej długości.

Słowa kluczowe: ryzyko długowieczności, Solvency II, wymagany poziom rezerw matematycznych. 